Bloch, H. and Rafiq, S. and Salim, R. 2015. Economic Growth with Coal, Oil and Renewable Energy Consumption in China: Prospects for Fuel Substitution. Economic Modelling. 44: pp. 104-115. 


\title{
Economic growth with coal, oil and renewable energy consumption in China: Prospects for fuel substitution
}

\begin{abstract}
We examine the relationship between Chinese aggregate production and consumption of three main energy commodities: coal, oil and renewable energy. Both autoregressive distributed lag (ARDL) and vector error correction modeling (VECM) show that Chinese growth is led by all three energy sources. Economic growth also causes coal, oil and renewables consumption, but with negative ownprice effects for coal and oil and a strong possibility of fuel substitution through positive cross-price effects. The results further show coal consumption causing pollution, while renewable energy consumption reduces emissions. No significant causation on emissions is found for oil. Hence, making coal expensive both absolutely and relatively to oil and renewable energy encourages shifting from coal to oil and renewable energy, thereby improving economic and environmental sustainability.
\end{abstract}

Keywords: China; fuel substitution; pollution; ARDL; error correction model; environmental sustainability.

JEL classifications: C22; Q43, Q48

\section{Highlights}

- Long run bi-directional causality is found between energy consumption of all three types and economic growth.

- Uni-directional causality is found running from coal consumption to pollutant emission, while the causality from oil or renewable energy to emission is insignificant.

- Long-run positive and significant impact of coal consumption on pollutant emission, while corresponding impact for renewable energy is negative and significant and for oil is insignificant.

- Negative own-price elasticities and positive cross-price elasticities are found for coal and oil, while no specific price elasticities for renewables are estimated due to lack of suitable data.

- $\quad$ Overall, results suggest good prospects for substitution from coal and oil to renewable energy by increasing fossil fuel prices.

Acknowledgment: The authors greatly appreciate helpful comments from reviewers of this journal, although accepting responsibility for any remaining errors or omissions. 


\section{Economic growth with coal and oil consumption in China: Prospects for fuel substitution}

\section{Introduction}

Climate change, geopolitical tensions and recent nuclear accidents have increased concerns about energy supply security and environmental impacts associated with energy production and consumption. As a result, several countries are currently proposing strong energy substitution policies and radical energy conservation measures. In this setting, it is important to assess the prospects for success of those policies, including potential impacts on economic growth (Goldemberg \& Lucon, 2010).

Despite the emergence of a bourgeoning literature on the nexus between energy consumption and economic growth, consensus remains elusive. Some of the probable reasons for not having any consensus in this area are using different data sets, alternative econometric methodologies and different countries' diverse characteristics (Ozturk, 2010).

Studies identifying the relationship between energy consumption (both at aggregate and disaggregate levels) and output primarily take two different approaches. The supply-side approach analyses the contribution of energy consumption in economic activities within the traditional production function framework (see, Stern, 2000; and Oh \& Lee, 2004). The demand-side approach analyses the relationship between energy consumption, gross domestic product (GDP) and energy prices in a tri-variate energy demand model (see, Asafu-Adjaye, 2000; and Rafiq \& Salim, 2007). All previous studies in this field follow one or the other of these two approaches and, on that basis, devise energy conservation policies. Application of both models concurrently potentially provides more robust estimates and more meaningful policy implications.

Fuel substitution is an energy policy instrument that can enhance sustainable development. To reduce global warming many countries are considering substituting oil, natural gas or renewable energy for coal, as coal exerts the most detrimental impact on environment. Hence, an empirical study analyzing this substitution prospect is warranted. To undertake meaningful policy insights in this regard this paper includes coal, oil and renewable energy in applying a combined supply-side and demand-side approach to Chinese data. We then discuss the possibilities for energy conservation and fuel substitution between coal, oil and renewable energy. Coal and oil have been selected as they are two major energy sources for the Chinese economy right at this moment and both have good price data 
available. Although prices of renewables are not available, we have included renewables consumption data and endeavor to infer the substitution possibilities.

Why is China a suitable case study? China has been on the 'news' for its spectacular GDP growth as well as high energy demand (particularly crude oil and coal) in recent years. China is the largest producer and consumer of coal in the world, and accounts for almost half of the world's coal consumption. Oil consumption in China is growing very fast in recent years and China is the second-largest consumer of oil behind the United States (EIA, 2014). Also China is widely blamed for high pollutant emission by media and civil society all around the world. Based on the amount and growth potential of demand for energy in the Chinese economy, it is now time to search for causal relationships between various forms of energy consumption and national output (GDP) in China and also for possible substitutability among the three major energy sources for environmental sustainability, coal, oil and renewables.

This paper adds two distinctive contributions to the existing literature. First, this is one of the very first papers to investigate the growth, energy and emission linkage in China by including oil, coal and renewable energy consumption to reach to robust energy conservation policy implications. Second, we examine fuel substitution relationships in China using advances in time-series methodology.

The rest of the paper is structured as follows. The next section presents an overview of the energy consumption profile of China. The third section provides a summary of findings on the relationship between energy consumption and economic growth in the last decade, Section 4 introduces the theoretical framework used in this paper, while description of data sources and methodologies are presented in Section 5. Section 6 presents the empirical results. Conclusions and policy implications are given in the final section.

\section{Energy Consumption in China: An Overview}

The Chinese economy has experienced phenomenal growth over the last three decades. Since the initiation of market reforms in 1978, China's growth has been about 10\% per annum (World Bank, 2013). Being the world's most populous country with a population of over 1.3 billion, this rapid economic growth has enabled China to lift more than 600 million people above the absolute poverty level. However, with strong economic growth, China's demand for energy, particularly for coal and oil has been surging, as has China's pollutant emission (Figure 1). According to British Petroleum [BP] (2013), in 2012, China is the largest 
consumer of coal in the world and also second largest consumer of crude oil with $50.3 \%$ and $12.1 \%$ of world total, respectively (see Table 1).

Table 1: Socio-economic and Oil Consumption Fact Sheet (2013) of China

\begin{tabular}{lc}
\hline Indicator(s) & Quantity \\
\hline Population, total (Millions) & 1357.38 \\
Percentage of world population & $19.05 \%$ \\
GDP (constant 2005 billion US\$) & 4864.00 \\
Percentage of World GDP & $8.69 \%$ \\
GDP growth (annual \%) & $7.67 \%$ \\
Coal consumption (million tonnes oil equivalent) & 1925.3 \\
Percentage of world coal consumption & $50.3 \%$ \\
Growth in coal consumption & $4.0 \%$ \\
Oil consumption (million tonnes) & 507.4 \\
Percentage of world oil consumption & $12.1 \%$ \\
Growth in oil consumption & $3.8 \%$ \\
Renewable electricity generation (quadrillion BTU) & 7.782 \\
Percentage of world renewable electricity generation & $18.13 \%$ \\
Growth in renewable electricity generation & $3.47 \%$ \\
\hline Source: Data of all the indicators except energy consumption is found from World Development Indicator \\
by World Bank while coal, oil and renewable energy consumption data is from BP Statistical Review, \\
nn1 s
\end{tabular}

Crompton \& Wu (2005) show that China consumed 31.0\% of the world's coal, $7.6 \%$ of oil, $10.7 \%$ of hydroelectricity and $1.2 \%$ of world's total gas in 2003 . More recent data reveal that the consumption figures for all these types of fuels have increased dramatically. For example, China accounted for $50.3 \%$ of the world's coal consumption, $12.1 \%$ of oil consumption, $24.1 \%$ of hydroelectricity consumption and $4.8 \%$ of gas consumption in 2013 (Appendix Table 1). The growth of output and energy consumption has environmental consequences, with enormous increases during this period in pollutant emission.

Figure 1: Real GDP, Coal, Oil and Renewable Energy Consumptions, and Carbon Emission

\section{Scenario in China}

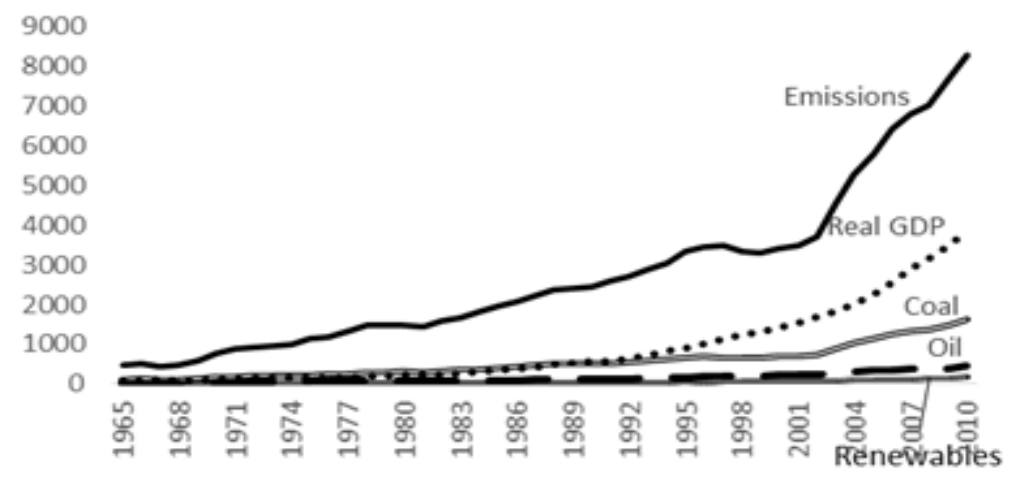

Note: Real GDP is in billion US 2005\$, coal, oil and renewables consumptions are in tonnes oil equivalent, carbon emission is in million tonnes carbon dioxide. Real GDP data is taken from World Development indicator; coal, oil, renewables consumption and emission are from BP.

According to Figure 2, China's coal production and consumption have been pretty much equal over the years. However, the gap between China's oil consumption and 
production is increasing, resulting in an increasing trend in oil imports since 1993. With respect to pollutant emission, oil is a better alternative source of energy than coal. Hence, substitution between coal and oil may help reduce the rate of increase in pollution emissions. Further, any substitution from both of these fossil fuels to renewable energy is truly welcome for its positive influence on pollution and exhaustion of non-renewable energy sources.

Figure 2: Coal and Oil Production and Consumption Scenario of China, 1981-2012
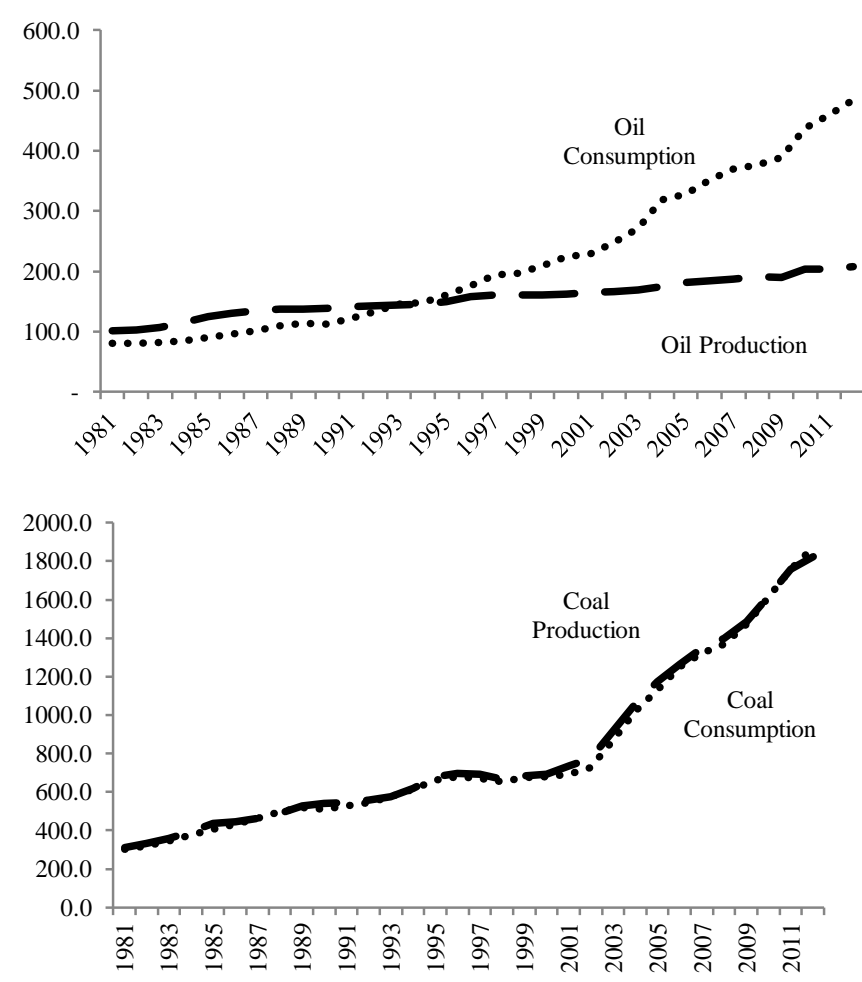

Source: BP (2013)

China substantially subsidizes energy prices to end users (Haley and Haley, 2008). Chinese retail prices for energy products are regulated according to location and the type of consumers. The Government maintains domestic price ceilings on finished energy products that are not consistent with the soaring international energy prices over the past decade. In particular, oil refineries get government subsidies to ease the gulf between low domestic prices compared to international energy prices.

The Chinese government has prioritized the expansion of natural gas-fired and renewable power plants as well as the electricity transmission system to connect more remote power sources to population centers (EIA, 2014). For example, the Three Gorges Dam hydroelectric facility, the largest hydroelectric project in the world, started construction in 2003 and completed construction in 2012. As a result, China has more renewable electricity generation capacity than any other country in the world (Dept. of Environment Australia 
2014). The country also leads the world in the production of many low-emissions technologies. In 2013 China invested US $\$ 56.3$ billion in renewable power and fuels, up from US\$2.4 billion in 2004 [Table 2]. In 2011 renewables made up a third of the country's new electricity generation capacity, making it the world's biggest investor in renewable energy (Dept. of Environment Australia 2014).

Table 2: Global Trends in Renewable Energy Investment 2013 data table, \$bn

\begin{tabular}{|c|c|c|c|c|c|c|c|c|c|c|c|}
\hline & 2004 & 2005 & 2006 & 2007 & 2008 & 2009 & 2010 & 2011 & 2012 & 2013 & $\begin{array}{l}\text { 2004-13 } \\
\text { CAGR \% }\end{array}$ \\
\hline $\begin{array}{l}\text { United } \\
\text { States }\end{array}$ & 5.5 & 11.7 & 28.2 & 33.6 & 35.9 & 23.5 & 34.7 & 53.4 & 39.7 & 35.8 & $23 \%$ \\
\hline Brazil & 0.6 & 2.6 & 4.6 & 11.0 & 12.2 & 7.8 & 7.7 & 9.7 & 6.8 & 3.1 & $21 \%$ \\
\hline $\begin{array}{l}\text { AMERICA } \\
\text { (excl. US \& } \\
\text { Brazil) }\end{array}$ & 1.4 & 3.3 & 3.2 & 3.2 & 5.8 & 6.1 & 11.5 & 8.7 & 9.9 & 12.4 & $27 \%$ \\
\hline Europe & 19.7 & 29.4 & 39.1 & 61.8 & 73.4 & 75.3 & 102.4 & 114.8 & 86.4 & 48.4 & $10 \%$ \\
\hline $\begin{array}{l}\text { Middle East } \\
\& \text { Africa }\end{array}$ & 0.5 & 0.5 & 0.9 & 1.6 & 2.3 & 1.4 & 4.3 & 3.2 & 10.4 & 9.0 & $37 \%$ \\
\hline China & 2.4 & 5.8 & 10.1 & 15.8 & 24.9 & 37.1 & 36.7 & 51.9 & 59.6 & 56.3 & $42 \%$ \\
\hline India & 2.5 & 2.9 & 4.4 & 6.3 & 5.4 & 4.2 & 8.7 & 12.6 & 7.2 & 6.1 & $10 \%$ \\
\hline $\begin{array}{l}\text { ASOC (excl. } \\
\text { China \& }\end{array}$ & 6.8 & 8.2 & 9.0 & 10.9 & 11.4 & 12.9 & 20.7 & 25.3 & 29.5 & 43.3 & $23 \%$ \\
\hline India) & & & & & & & & & & & \\
\hline Total & 39.5 & 64.5 & 99.6 & 145.9 & 171.2 & 168.4 & 226.7 & 279.4 & 249.5 & 214.4 & $21 \%$ \\
\hline
\end{tabular}

Source: Bloomberg New Energy Finance and UNEP data, from Frankfurt School UNEP Collaborating Centre for Climate and Sustainable Energy Finance, Global Trends in Renewable Energy Investment 2014

\section{Evidence on Energy Consumption and Economic Growth}

Since the seminal paper of Kraft \& Kraft (1978), literature on the energy consumption and growth nexus has been growing in all sorts of directions. The notion that energy consumption is one of the basic indicators of economic development has attracted economists from all over the world to investigate the relationship between energy consumption and economic growth (many studies are summarized in Tugcu et. al. (2012)). Research on this issue has been aimed at providing policy guidelines in designing efficient energy conservation policies. 
Tugcu et. al. (2012) characterize the literature relating energy consumption to economic growth with four hypotheses about causality dynamics. The first hypothesis comprises studies that find that energy consumption leads to economic growth, the 'growth hypothesis', include Wolde-Rufael (2004) and others. Second, studies that find bi- directional causality, the 'feedback hypothesis', include Belke et. al. (2011) and Fuinhas \& Marques (2012). Uni-directional causality from economic growth to energy consumption, the 'conservation hypothesis', is found by Narayan \& Smyth (2005) among others, while Stern (1993), and others cannot find any causality at all, the 'neutrality hypothesis'. There are also studies that find mixed conclusions, like Asafu-Adjaye (2000) and Soytas \& Sari (2006).

Since the Stern (1993) paper that questions the appropriateness of a bivariate approach in the light of omitted variable problems, research in this area takes one of two basic approaches. First, a multivariate supply-side or production-side approach, with energy consumption, GDP, capital and labor as variables (for example, Stern, 1993 and Oh \& Lee, 2004). Second, a demand-side approach with energy consumption, GDP and prices (for example, Masih \& Masih (1997), Asafu-Adjaye (2000), Rafiq \& Salim (2009)).

In a recent paper, Apergis \& Tang (2013) investigate the validity of the energy-led growth hypothesis using a different model specification and different stages of economic development for 85 selected countries around the globe. Overall, the authors find a systematic pattern, although the causality results are mixed among countries. In particular, the results for developed and developing countries provide more support the energy-led growth hypothesis compared to the less developed or low-income countries.

Early studies of energy consumption and growth in China are Ma et. al. (2008) and Wolde-Rufael (2009), while two recent papers involving China are Zhang \& Xu, (2012) and Shahbaz et. al. (2013). Shahbaz et. al. (2013) analyze the dynamic relationship between energy use and economic growth in China by incorporating financial development, international trade and capital in their multivariate model, finding unidirectional causality running from energy consumption to economic growth from 1971 to 2011 . Zhang \& Xu, (2012) examine the causal relationship between energy consumption and economic growth in its regional and sectoral aspects by adopting provincial panel data in China from 1995 to 2008. In contrast to Shahbaz et. al. (2013), the findings support the conservation hypothesis for China at both national and sectorial levels.

Interestingly, none of the above mentioned studies include carbon emission, even though carbon emission is an important by-product of energy consumption. However, the model of Govindaraju \& Tang (2013) does include pollutant emission along with coal 
consumption and economic growth in China and India. They find strong evidence of unidirectional causality running from economic growth to $\mathrm{CO}_{2}$ emissions in China in both the short and long run, while there is only a short-run uni-directional Granger causality running from economic growth to coal consumption in India. Bloch et. al. (2012) investigate the linkage between coal consumption, emission and growth in China by estimating both supplyside and demand-side frameworks. Using data from 1977 to 2008 for the supply-side and 1965 to 2008 for demand-side, they find evidence supporting the conservation hypothesis for China.

The present article fills a gap in the existing literature by including coal, oil and renewable energy separately as well as together in the supply-side and demand-side models for China. Including coal, oil as well as renewable energy allows us to examine the causality for each energy input separately and also to investigate possible pollution reduction through fuel substitution from coal to oil and/or renewable energy. Further, this study employs both autoregressive distributed lag (ARDL) and Johansen vector error correction (VECM) models along with some recent techniques for checking the robustness of the results.

\section{Theoretical Settings}

This study analyzes the relationship between coal, oil and renewable energy consumption and economic activity from both supply-side and demand-side perspectives. For identifying fuel substitution possibilities, within each of the models we use two separate frameworks, one in which coal, oil and renewable energy consumption are included individually and another in which coal, oil and renewables are combined into a single energy measure.

The supply-side approach is based on an energy inclusive Cobb-Douglas type production function. The two supply-side models take the following multiplicative forms,

$$
Y_{t}=A_{t} K_{t}^{\alpha} L_{t}^{\beta} C_{t}^{\chi} O_{t}^{\gamma} R E_{t}^{\varphi} \varepsilon_{t}
$$

and, $Y_{t}=A_{t} K_{t}^{\alpha} L_{t}^{\beta} C O R E_{t}^{\omega} \varepsilon_{t}$

where, $Y_{t}$ indicates aggregate output at time $t, K_{t}$ is the flow of services provided by the existing capital stock, $L_{t}$ is the labour employed in production, $A_{t}$ is the level of technology, which is also the measure of total factor productivity, $C_{t}$ is coal consumption, $O_{t}$ is oil consumption, $R E_{t}$ is renewable energy consumption and $C O R E_{t}$ is the energy measure for combined coal, oil and renewable energy consumption. $\alpha, \beta, \chi, \gamma, \varphi$ and $\omega$ are 
estimated parameters that measure the elasticity of output with respect to capital, labour, coal, oil, renewable energy and combined energy measure, respectively.

Studies using the demand-side approach mainly focus on estimating the impact of economic activities on energy consumption. As mentioned above, most of these studies adopt a tri-variate framework consisting of energy consumption, income and CPI, where CPI is used as a proxy for energy prices. Instead of CPI, we utilise prices for coal and oil. Since there is a lack of renewable energy price data with respect to China for the whole studied period, we exclude the price of renewable energy. ${ }^{1}$ For the combined price of coal and oil we develop a weighted chain-linked Fisher Index.

Pollution emissions are recognized as a by-product of energy consumption and output. Thus, we include an equation for $\mathrm{CO}_{2}$ emissions in a second demand-side model. The second demand-side model then encompasses the dynamic relationship among each type of energy consumption, income, oil price, coal price and $\mathrm{CO}_{2}$ emissions. Alternatively, we combine all forms of energy consumption into a single index and use the combined price of coal and oil along with income and emissions variables.

The first demand-side model examines the relationship among aggregate output and coal consumption, oil consumption, renewable energy consumption or combined coal, oil and renewables within the following framework:

$$
\begin{aligned}
& C_{t}=Y_{t}^{\delta} C P_{t}^{\theta} O P_{t}^{\lambda} \varepsilon_{t} \\
& O_{t}=Y_{t}^{\delta} C P_{t}^{\theta} O P_{t}^{\lambda} \varepsilon_{t} \\
& R E_{t}=Y_{t}^{\delta} C P_{t}^{\theta} O P_{t}^{\lambda} \varepsilon_{t} \\
& C O R E_{t}=Y_{t}^{\delta} C O P_{t}^{v}
\end{aligned}
$$

where, $C_{t}$ is coal consumption, $O_{t}$ is oil consumption, $R E_{t}$ is renewable energy consumption, $C O R E_{t}$ is combined oil, coal and renewables consumption, $Y_{t}$ is income, $C P_{t}$ is coal price, $O P_{t}$ is oil price and $C O P_{t}$ is combined coal and oil price index and $\delta, \theta, \lambda$ and $v$ are estimated parameters that measure the elasticity of aggregate output, coal price, oil prices and combined price index, respectively.

The second set of demand-side equations is for examining the dynamic relationship among carbon emissions, output, coal, oil, renewable energy and their combined

\footnotetext{
${ }^{1}$ Omission of a renewable energy price variable might bias the estimated coefficients of remaining variables. However, much use of renewable energy in China is mandated by government policy rather than a response to market price signals, suggesting that the bias from omitting an energy price variable might be low.
} 
consumption and is as follows:

$$
\begin{aligned}
& E_{t}=Y_{t}^{\xi} C_{t}^{\Pi} O_{t}^{\zeta} R E_{t}^{\rho} \varepsilon_{t} \\
& E_{t}=Y_{t}^{\xi} \operatorname{COR} E_{t}^{\Gamma} \varepsilon_{t}
\end{aligned}
$$

where, $E$ is carbon emission and $\xi, \Pi, \zeta, \rho$ and $\Gamma$ are the elasticity of carbon emission with respect to output, coal, oil, renewable energy and combined energy consumption, respectively.

\section{Data Sources and Analytical Framework}

\subsection{Data sources}

We use annual data from 1977 to 2013 and 1965 to 2011 for the supply-side and demand-side analyses, respectively. The rationale behind selecting these periods is the availability of data. Variables used in supply-side analysis are output, labor, capital, coal consumption, oil consumption, renewable energy consumption and combined energy consumption, while in the demand-side analysis the variables are income, coal consumption, oil consumption, renewable energy, combined energy consumption, coal price, crude oil price, combined coal and oil price index and carbon emissions. Since there are no renewable price data on China available over the studied period, we could not include the renewables price in our analyses.

Output and capital are measured by constant-dollar GDP and constant-dollar gross fixed gross capital formation, respectively. Constant-dollar gross domestic product and constant-dollar fixed gross capital formation data are collected from World Development Indicators (WDI) of July 2013. The base year for both of these series is 2005. The labor variable measures the general level of employment collected from LABORSTA Labor Statistics Database, an online publication of International Labor Organization (ILO).

Coal, oil and renewable energy consumption data are collected from the Statistical Review of World Energy, 2014 published by British Petroleum (BP). Coal and oil prices constructed from the data series of international coal and oil prices, which are adjusted with the official exchange rate between Chinese and US currency. International coal and oil prices are in US dollars per barrel oil equivalent and are collected from British Petroleum (BP) Statistical Review, 2014. The official exchange rate is collected from World Development Indicators (WDI), 2013. The price series for combined coal and oil is a weighted chain-linked Fisher Price Index, where the weights are the current share of coal or oil in the total combined value of coal and oil consumption in that year. The Fisher index is often termed as 'ideal' because it gets around the practical problem of 'time reversal'. Total carbon emission data are collected from WDI, 2014. All the series are converted to their logarithmic forms. Visual 
presentations of these series for the supply-side and demand-side analyses are given in Appendix Figure 1a and 1b, respectively.

\subsection{Analytical Framework}

The empirical estimation is carried out with three objectives. First is to understand how the variables are linked in the long run; second is to find the dynamic causal relationship among the variables; and the third is to investigate the robustness of the causality directions and magnitudes. To achieve these objectives with robust results we employ the ARDL bound testing approach along with a dynamic vector error correction model that includes dummy variables for structural breaks. We further investigate long-run cointegrating relationships and causality dynamics among the variables through Johansen (1988) and Johansen \& Juselius (1990) maximum likelihood co-integration tests.

Prior to implementing the model it is imperative to use unit-root tests to ensure first that the underlying data are non-stationary at level but become stationary at their first difference or $I(1)$ and there exists at least one cointegrating relationship among variables. Three of the most widely used unit-root tests are the Augmented Dicky-Fuller (ADF), Phillips Perron (PP) and Kwiatkowski-Phillips-Schmidt-Shin (KPSS) tests. All three tests are applied in this study. However, these standard tests may not be appropriate when the series contain structural breaks (Salim \& Bloch, 2009). Therefore, the data are also scrutinized for possible structural break(s) during the studied periods.

Perron (1989) points out that ignoring structural breaks in the trend function leads to considerable power reduction of traditional unit-root tests. However, Perron's (1989) assumption of an unknown exogenous break point is criticized due of its tendency to favor the alternative hypothesis. The assumption of a single break point is criticized because of a loss of information from considering just one break instead of two, three or even more. We employ relatively new and more powerful methods of Lee \& Strazicich (2003 and 2004) to test the existence of possible structural break(s).

Once the time-series properties of the variables are established, we perform the ARDL bounds testing approach in presence of structural break. This procedure has several advantages. It is flexible and applies regardless of the order of integration of the variables. According to Pesaran \& Shin (1999), simulation results show that this approach is superior and delivers consistent results for even a small sample. Furthermore, through performing a simple linear transformation of the ARDL bounds testing method it is possible to derive a dynamic unrestricted error correction model (UECM). The resultant UECM can then easily 
integrate the short-run dynamics with the long-run equilibrium without losing any long-run information. Hence, we estimate the following ARDL model: ${ }^{2}$

$$
\begin{aligned}
& \Delta \ln Y_{t}=\alpha_{1}+\alpha_{t} T+\alpha_{D} D+\alpha_{Y} \ln Y_{t-1}+\alpha_{K} \ln K_{t-1}+\alpha_{L} \ln L_{t-1}+\alpha_{C} \ln C_{t-1}+\alpha_{O} \ln O_{t-1}+ \\
& \alpha_{R E} \ln R E_{t-1}+\sum_{i=0}^{p} \alpha_{i} \Delta \ln Y_{t-i}+\sum_{j=0}^{q} \alpha_{j} \Delta \ln K_{t-j}+\sum_{k=0}^{r} \alpha_{k} \Delta \ln L_{t-k}+\sum_{l=0}^{s} \alpha_{l} \Delta \ln C_{t-l}+ \\
& \sum_{m=0}^{t} \alpha_{m} \Delta \ln O_{t-m}+\sum_{n=0}^{u} \alpha_{n} \Delta \operatorname{lnR} E_{t-n}+\pi_{1 t} \\
& \Delta \ln K_{t}=\beta_{1}+\beta_{t} T+\beta_{D} D+\beta_{Y} \ln Y_{t-1}+\beta_{K} \ln K_{t-1}+\beta_{L} \ln L_{t-1}+\beta_{C} \ln C_{t-1}+\beta_{O} \ln O_{t-1}+ \\
& \beta_{R E} \ln R E_{t-1}+\sum_{i=0}^{p} \beta_{i} \Delta \ln Y_{t-i}+\sum_{j=0}^{q} \beta_{j} \Delta \ln K_{t-j}+\sum_{k=0}^{r} \beta_{k} \Delta \ln L_{t-k}+\sum_{l=0}^{s} \beta_{l} \Delta \ln C_{t-l}+ \\
& \sum_{m=0}^{t} \beta_{m} \Delta \ln O_{t-m}+\sum_{n=0}^{u} \beta_{n} \Delta \ln R E_{t-n}+\pi_{2 t} \\
& \Delta \ln L_{t}=\lambda_{1}+\alpha_{t} T+\lambda_{D} D+\lambda_{Y} \ln Y_{t-1}+\lambda_{K} \ln K_{t-1}+\lambda_{L} \ln L_{t-1}+\lambda_{C} \ln C_{t-1}+\lambda_{o} \ln O_{t-1}+ \\
& \lambda_{R E} \ln R E_{t-1}+\sum_{i=0}^{p} \lambda_{i} \Delta \ln Y_{t-i}+\sum_{j=0}^{q} \lambda_{j} \Delta \ln K_{t-j}+\sum_{k=0}^{r} \lambda_{k} \Delta \ln L_{t-k}+\sum_{l=0}^{s} \lambda_{l} \Delta \ln C_{t-l}+ \\
& \sum_{m=0}^{t} \lambda_{m} \Delta \ln O_{t-m}+\sum_{n=0}^{u} \lambda_{n} \Delta \ln R E_{t-n}+\pi_{3 t} \\
& \Delta \ln C_{t}=\vartheta_{1}+\vartheta_{t} T+\vartheta_{D} D+\vartheta_{Y} \ln Y_{t-1}+\vartheta_{K} \ln K_{t-1}+\vartheta_{L} \ln L_{t-1}+\vartheta_{C} \ln C_{t-1}+\vartheta_{O} \ln O_{t-1}+ \\
& \vartheta_{R E} \ln R E_{t-1}+\sum_{i=0}^{p} \vartheta_{i} \Delta \ln Y_{t-i}+\sum_{j=0}^{q} \vartheta_{j} \Delta \ln K_{t-j}+\sum_{k=0}^{r} \vartheta_{k} \Delta \ln L_{t-k}+\sum_{l=0}^{s} \vartheta_{l} \Delta \ln C_{t-l}+ \\
& \sum_{m=0}^{t} \vartheta_{m} \Delta \ln O_{t-m}+\sum_{n=0}^{u} \vartheta_{n} \Delta \ln R E_{t-n}+\pi_{4 t} \\
& \Delta \ln O_{t}=\rho_{1}+\rho_{t} T+\rho_{D} D+\rho_{Y} \ln Y_{t-1}+\rho_{K} \ln K_{t-1}+\rho_{L} \ln L_{t-1}+\rho_{C} \ln C_{t-1}+\rho_{O} \ln O_{t-1}+ \\
& \rho_{R E} \ln R E_{t-1}+\sum_{i=0}^{p} \rho_{i} \Delta \ln Y_{t-i}+\sum_{j=0}^{q} \rho_{j} \Delta \ln K_{t-j}+\sum_{k=0}^{r} \rho_{k} \Delta \ln L_{t-k}+\sum_{l=0}^{s} \rho_{l} \Delta \ln C_{t-l}+ \\
& \sum_{m=0}^{t} \rho_{m} \Delta \ln O_{t-m}+\sum_{n=0}^{u} \rho_{n} \Delta \ln R E_{t-n}+\pi_{5 t} \\
& \Delta \operatorname{lnR} E_{t}=\tau_{1}+\tau_{t} T+\tau_{D} D+\tau_{Y} \ln Y_{t-1}+\tau_{K} \ln K_{t-1}+\tau_{L} \ln L_{t-1}+\tau_{C} \ln C_{t-1}+\tau_{O} \ln O_{t-1}+ \\
& \tau_{R E} \ln R E_{t-1}+\sum_{i=0}^{p} \tau_{i} \Delta \ln Y_{t-i}+\sum_{j=0}^{q} \tau_{j} \Delta \ln K_{t-j}+\sum_{k=0}^{r} \tau_{K} \Delta \ln L_{i-K}+\sum_{l=0}^{s} \tau_{l} \Delta \ln C_{i-l}+ \\
& \sum_{m=0}^{t} \tau_{m} \Delta \ln O_{t-m}+\sum_{n=0}^{u} \tau_{n} \Delta \operatorname{lnR} E_{t-n}+\pi_{6 t}
\end{aligned}
$$

where, $\Delta$ is the difference operator, $T$ is time trend and $D$ indicates common structural break point based on the findings of the Lee \& Strazicich (2003 and 2004) tests.

Testing cointegration involves comparing the compound $F$-statistics with the upper critical bound (UCB) and lower critical bound (LCB) (Pesaran et. al. (2001). The null hypothesis $H_{0}: \alpha_{Y}=\alpha_{K}=\alpha_{L}=\alpha_{C}=\alpha_{O}=0$ of no cointegration [in equation 9] is tested against alternate $H_{1}: \alpha_{Y} \neq \alpha_{K} \neq \alpha_{L} \neq \alpha_{C} \neq \alpha_{O} \neq 0$ of cointegration. ${ }^{3}$ The series are cointegrated if the computed $F$-statistic lies above the UCB; and not cointegrated if the computed $F$-statistics is below the LCB; while if the computed $F$-statistics is between UCB

\footnotetext{
${ }^{2}$ For greater understanding, from this point onward we will be elaborating all the models based on the model in Equation (1).

${ }^{3}$ Pesaran et al. (2001) provide two critical values, when the regressors are $I(0)$ and when they are $I(1)$.
} 
and LCB, the test is uncertain. ${ }^{4}$ We use critical bounds from Narayan (2005), which are more appropriate for a small sample, 47 and 36 observations in this case. The parameter stability test is checked by applying the CUSUM test proposed by Brown et. al. (1975). This study also employs the Chow forecast test for examining structural breaks in the data.

For the long-run relation among the variables the following equation is used:

$\ln Y_{t}=\theta_{0}+\theta_{1} \ln K_{t}+\theta_{2} \ln L_{t}+\theta_{3} \ln C_{t}+\theta_{4} \ln O_{t}+\theta_{5} \ln R E_{t}+\mu_{i}$

where, $\theta_{0}=-\beta_{1} / \alpha_{Y}, \theta_{1}=-\alpha_{K} / \beta_{1}, \theta_{2}=-\alpha_{L} / \beta_{1}$, $\theta_{3}=-\alpha_{C} / \beta_{1}, \theta_{4}=-\alpha_{O} / \beta_{1}, \theta_{5}=-\alpha_{R E} / \beta_{1}$ and $\mu_{t}$ is the 'white noise' error term. Finally, to ensure robustness of the causality findings, we perform generalized forecast error variance decompositions as suggested by Koop et. al. (1996) and Pesaran \& Shin (1998).

\section{Empirical analysis}

\subsection{Time series properties of data}

Prior to carrying out unit root tests for the variables, we first test for the appropriateness of the logarithmic transformation of each of the variables in Equations (1) to (8). The test results indicate that the natural logarithmic transformations of all the equations are appropriate for unit-root testing. ${ }^{5}$ Augmented Dickey-Fuller $(A D F)$, Phillips Perron $(P P)$ and KwiatkowskiPhillips-Schmidt-Shin (KPSS) unit root tests are employed to examine the stationarity of underlying time-series data. The results of unit root tests reveal that all the concerned variables are non-stationary at levels but stationary at their first differences. ${ }^{6}$ We also employ Lee \& Strazicich (2003 and 2004) tests for one and two structural breaks. The results of these tests are provided in Table 3 . Since the null cannot be rejected for most of the break dates $\left(B_{t}\right.$, $B_{t 1}$ and $B_{t 2}$ ), we conclude that all the series are non-stationary at level while stationary at their first differences. This confirms that all the variables in both the supply-side and demand-side models are integrated at $I(1)$.

The break dates from both of the tests are pretty consistent with each other. Hence, we take at least one statistically significant break date which is common from both the tests into our analysis. For output, coal consumption, oil consumption, renewable energy consumption, combined energy consumption, oil price, combined coal and oil price and pollutant emission the dates of the breaks lie around 2002, 1973, 2003, 1969, 1973, 1973 and 1997 , respectively.

\footnotetext{
${ }^{4}$ Under such circumstances, Bannerjee et.al. (1998) suggests that the error correction method is appropriate.

${ }^{5}$ Results not reported considering space limitation. However, results will be provided upon request.

${ }^{6}$ Results not reported here due to the space limitation. However, the authors will provide detailed results upon request.
} 
Table 3: Structural Break Tests

\begin{tabular}{|c|c|c|c|c|c|c|c|c|c|c|}
\hline & \multicolumn{4}{|c|}{$\begin{array}{l}\text { LM One Break Unit Root Test } \\
\text { of Lee and Strazicich (2004) }\end{array}$} & \multicolumn{6}{|c|}{$\begin{array}{l}\text { LM Two Break Unit Root Test of Lee and Strazicich } \\
\qquad(2003)\end{array}$} \\
\hline Series & $\mathrm{K}$ & $\mathrm{TB}$ & $S_{t-1}$ & $\mathrm{~B}_{\mathrm{t}}$ & $\mathrm{k}$ & TB1 & TB2 & $S_{t-1}$ & $\mathrm{~B}_{\mathrm{t} 1}$ & $\mathrm{~B}_{\mathrm{t} 2}$ \\
\hline \multicolumn{11}{|c|}{$\underline{\text { Supply-side Analysis }}$} \\
\hline LY & 3 & 2001 & $\begin{array}{c}-0.172 \\
{[-1.518]}\end{array}$ & $\begin{array}{l}-2.030^{*} \\
{[-3.404]}\end{array}$ & 0 & 1998 & 2001 & $\begin{array}{l}-0.305 \\
{[-2.285]}\end{array}$ & $\begin{array}{c}-0.013 \\
{[-1.135]}\end{array}$ & $\begin{array}{l}-1.212^{*} \\
{[-4.072]}\end{array}$ \\
\hline LL & 1 & 1983 & $\begin{array}{c}-0.074 \\
{[-1.079]}\end{array}$ & $\begin{array}{c}0.006 \\
{[0.500]}\end{array}$ & 4 & 1983 & 2009 & $\begin{array}{c}-0.081 \\
{[-1.107]}\end{array}$ & $\begin{array}{c}0.005 \\
{[0.471]}\end{array}$ & $\begin{array}{c}-0.009 \\
{[-0.776]}\end{array}$ \\
\hline LK & 2 & 1989 & $\begin{array}{l}-0.389 \\
{[-2.695]}\end{array}$ & $\begin{array}{c}-0.031 \\
{[-0.876]}\end{array}$ & 8 & 1988 & 1991 & $\begin{array}{c}-0.439 \\
{[-2.858]}\end{array}$ & $\begin{array}{c}-0.063 \\
{[-2.168]}\end{array}$ & $\begin{array}{c}0.083 \\
{[3.038]}\end{array}$ \\
\hline LC & 5 & 2001 & $\begin{array}{c}-0.099 \\
{[-1.248]}\end{array}$ & $\begin{array}{c}-0.014 \\
{[-0.644]}\end{array}$ & 2 & 1997 & 2003 & $\begin{array}{c}-0.121 \\
{[-1.368]}\end{array}$ & $\begin{array}{c}-0.042 \\
{[-2.429]}\end{array}$ & $\begin{array}{c}0.042 \\
{[2.474]}\end{array}$ \\
\hline LO & 0 & 1973 & $\begin{array}{c}-0.114 \\
{[-1.348]}\end{array}$ & $\begin{array}{c}-0.045 \\
{[-2.288]}\end{array}$ & 7 & 1973 & 1979 & $\begin{array}{c}-0.129 \\
{[-1.413]}\end{array}$ & $\begin{array}{c}-0.045 \\
{[-2.307]}\end{array}$ & $\begin{array}{c}-0.014 \\
{[-0.713]}\end{array}$ \\
\hline LRE & 1 & 2009 & $\begin{array}{l}-0.125 \\
{[-1.486]}\end{array}$ & $\begin{array}{c}0.055 \\
{[1.717]}\end{array}$ & 2 & 1990 & 2009 & $\begin{array}{c}-0.155 \\
{[-1.643]}\end{array}$ & $\begin{array}{c}-0.047 \\
{[-1.518]}\end{array}$ & $\begin{array}{c}0.054 \\
{[1.719]}\end{array}$ \\
\hline LCORE & 2 & 2002 & $\begin{array}{c}-0.100 \\
{[-1.320]}\end{array}$ & $\begin{array}{c}0.031 \\
{[1.917]}\end{array}$ & 1 & 2002 & 2009 & $\begin{array}{c}-0.122 \\
{[-1.445]}\end{array}$ & $\begin{array}{c}0.031 \\
{[1.946]}\end{array}$ & $\begin{array}{c}0.024 \\
{[1.641]}\end{array}$ \\
\hline \multicolumn{11}{|c|}{ Demand-side Analysis } \\
\hline LY & 2 & 2001 & $\begin{array}{c}-0.138 \\
{[-1.741]}\end{array}$ & $\begin{array}{c}-0.050 \\
{[-2.625]}\end{array}$ & 6 & 1998 & 2001 & $\begin{array}{c}-0.311 \\
{[-2.273]}\end{array}$ & $\begin{array}{c}-0.013 \\
{[-1.123]}\end{array}$ & $\begin{array}{c}-0.009 \\
{[-0.812]}\end{array}$ \\
\hline LC & 1 & 2002 & $\begin{array}{c}-0.172 \\
{[-1.965]}\end{array}$ & $\begin{array}{l}0.080^{*} \\
{[3.338]}\end{array}$ & 5 & 1997 & 2002 & $\begin{array}{c}-0.208 \\
{[-2.157]}\end{array}$ & $\begin{array}{c}0.080 \\
{[1.417]}\end{array}$ & $\begin{array}{c}-0.047 \\
{[-3.417]}\end{array}$ \\
\hline LO & 7 & 1973 & $\begin{array}{c}-0.043 \\
{[-0.949]}\end{array}$ & $\begin{array}{l}0.108^{*} \\
{[3.220]}\end{array}$ & 3 & 1973 & 1978 & $\begin{array}{c}-0.049 \\
{[-1.005]}\end{array}$ & $\begin{array}{c}0.109 \\
{[3.253]}\end{array}$ & $\begin{array}{c}0.038 \\
{[1.058]}\end{array}$ \\
\hline LRE & 0 & 2003 & $\begin{array}{c}-0.322 \\
{[-2.842]}\end{array}$ & $\begin{array}{c}0.037 * * \\
{[4.154]}\end{array}$ & 1 & 1990 & 2003 & $\begin{array}{c}-0.382 \\
{[-3.114]}\end{array}$ & $\begin{array}{l}-0.047 \\
{[-.529]}\end{array}$ & $\begin{array}{c}0.035 \\
{[3.124]}\end{array}$ \\
\hline LCORE & 3 & 1969 & $\begin{array}{c}-0.121 \\
{[-1.645]}\end{array}$ & $\begin{array}{l}0.08 * * \\
{[3.610]}\end{array}$ & 0 & 1969 & 1989 & $\begin{array}{c}-0.146 \\
{[-1.800]}\end{array}$ & $\begin{array}{c}0.08 * \\
{[3.624]}\end{array}$ & $\begin{array}{c}-0.029 \\
{[-1.324]}\end{array}$ \\
\hline LE & 8 & 1997 & $\begin{array}{c}-0.170 \\
{[-1.954]}\end{array}$ & $\begin{array}{c}0.101 \text { ** } \\
{[3.688]}\end{array}$ & 1 & 1997 & 2001 & $\begin{array}{c}-0.203 \\
{[-2.126]}\end{array}$ & $\begin{array}{l}0.102^{*} \\
{[3.791]}\end{array}$ & $\begin{array}{c}-0.054 \\
{[-1.991]}\end{array}$ \\
\hline LCP & 3 & 1998 & $\begin{array}{c}-0.359 \\
{[-2.996]}\end{array}$ & $\begin{array}{c}-0.044 \\
{[-0.942]}\end{array}$ & 6 & 1974 & 1998 & $\begin{array}{c}-0.409 \\
{[-3.209]}\end{array}$ & $\begin{array}{c}0.060 \\
{[1.214]}\end{array}$ & $\begin{array}{c}-0.043 \\
{[-0.906]}\end{array}$ \\
\hline LOP & 8 & 1973 & $\begin{array}{c}-0.70 * * \\
{[-4.711]}\end{array}$ & $\begin{array}{l}0.468^{*} \\
{[3.298]}\end{array}$ & 5 & 1973 & 2004 & $\begin{array}{l}-0.8 * * * * \\
{[-5.032]}\end{array}$ & $\begin{array}{c}0.452 \\
{[3.257]}\end{array}$ & $\begin{array}{c}0.241 \\
{[1.714]}\end{array}$ \\
\hline LCOP & 0 & 1973 & $\begin{array}{l}-0.7 * * * \\
{[-4.805]}\end{array}$ & $\begin{array}{c}-0.134 \\
{[-1.683]}\end{array}$ & 4 & 1973 & 1989 & $\begin{array}{c}-0.7 * * * \\
{[-4.880]}\end{array}$ & $\begin{array}{c}0.292 * * \\
{[4.144]}\end{array}$ & $\begin{array}{c}0.082 \\
{[1.156]}\end{array}$ \\
\hline
\end{tabular}

The results reveal a significant break for renewable energy consumption in 2003 . This is also not surprising. The Chinese government started its own renewable energy program in the 1990s. From 1994 to 2004 nearly 20 policies and regulations have been carried out. All 
these policies started to have a combined impact on renewables market within a decade. Some of these include: Wind Power Grid Regulations Act 1994, China Electric Power Act 1995, China Energy Conservation Law Act 1998, etc. The break in 1997 for pollution might be linked with huge increase in Chinese energy imports, especially oil. In response to the rapidly growing demand for energy and deteriorating prospect for major new energy discoveries, Chinese political leadership and marginal elite have started to encourage energy imports from foreign sources. By 1997 the number of countries exporting more than two million tonnes of crude oil to China had doubled from 1990 (Umbach, Frank. 2010).

\subsection{Co-integration tests}

As the variables are non-stationary in levels and stationary in first differences, both ARDL and Johansen (1988) and Johansen and Juselius (1990) maximum likelihood co-integration tests are employed to examine if the variables are cointegrated. ARDL test results are reported in Table 4. This bound test is sensitive to lag length, so we use the Akaike Information Criteria (AIC) to determine the optimal lag lengths that are reported in column 2 of Table $4 .^{7}$ According to ARDL results long-run cointegrating relationships exist among all the variables in every single equation.

Table 4: ARDL Cointegration Test

\begin{tabular}{|c|c|c|c|c|c|c|c|}
\hline \multicolumn{4}{|c|}{ Bounds testing to cointegration } & \multicolumn{4}{|c|}{ Diagnostic tests } \\
\hline $\begin{array}{l}\text { Estimated } \\
\text { models }\end{array}$ & $\begin{array}{l}\text { Optimal } \\
\text { lag }\end{array}$ & $\begin{array}{l}\text { Structur- } \\
\text { al break }\end{array}$ & $\begin{array}{l}\text { F- } \\
\text { statistics }\end{array}$ & $\begin{array}{l}\chi^{2} \\
\text { NORMAL }\end{array}$ & $\begin{array}{l}\chi^{2} \\
\mathrm{ARCH}\end{array}$ & $\begin{array}{l}\chi^{2} \\
\text { RESET }\end{array}$ & $\begin{array}{l}\chi^{2} \\
\text { SERIAL }\end{array}$ \\
\hline \multicolumn{8}{|c|}{ Supply-side Analysis } \\
\hline $\begin{array}{l}\text { LY/LL, LK, LC, } \\
\text { LO, LRE }\end{array}$ & $\begin{array}{l}1,0,2,0 \\
2,0\end{array}$ & 2001 & $3.973 * *$ & [2]:0.690 & [1] 0.054 & {$[1]: 0.875$} & {$[1] 0.278$} \\
\hline $\begin{array}{l}\text { LY/LL, LK, } \\
\text { LCORE }\end{array}$ & $2,0,2,2$ & 2001 & $3.763 * *$ & {$[2]: 1.672$} & {$[1]: 0.003$} & {$[1]: 3.067$} & {$[1] 0.207$} \\
\hline \multicolumn{8}{|c|}{$\underline{\text { Demand-side Analysis }}$} \\
\hline $\begin{array}{l}\text { LC/LY, LCP, } \\
\text { LOP }\end{array}$ & $2,2,2,0$ & 2002 & $3.351 * *$ & {$[2]: 0.441$} & {$[1]: 2.855$} & {$[1]: 1.395$} & {$[1] 0.146$} \\
\hline $\begin{array}{l}\text { LO/LY, LCP, } \\
\text { LOP }\end{array}$ & $2,1,2,0$ & 1973 & $2.735^{* *}$ & [2]:0.441 & {$[1]: 3.344$} & {$[1]: 0.577$} & {$[1] 0.047$} \\
\hline $\begin{array}{l}\text { LRE/LY, LCP, } \\
\text { LOP }\end{array}$ & $1,2,1,0$ & 2003 & $3.613^{* *}$ & [2]:0.108 & {$[1]: 4.253$} & {$[1]: 3.058$} & [1]:0.865 \\
\hline $\begin{array}{l}\text { LCORE/LY, } \\
\text { LCOP }\end{array}$ & $3,1,4$ & 1969 & $2.635^{* *}$ & [2]:0.019 & {$[1]: 0.272$} & {$[1]: 0.753$} & [1]:0.904 \\
\hline $\begin{array}{l}\text { LE/LY, LC, LO, } \\
\text { LRE }\end{array}$ & $\begin{array}{l}1,2,1,0, \\
4\end{array}$ & 1997 & $3.612 * *$ & {$[2]: 1.503$} & [1]:0.043 & {$[1]: 3.577$} & {$[1] 0.687$} \\
\hline LE/LY, LCORE & $2,0,2$ & 1997 & $2.204 * *$ & [2]:3.346 & [1]:0.436 & [1]:3.002 & [1]0.112 \\
\hline
\end{tabular}

\footnotetext{
${ }^{7}$ In order to determine how many lags to use, several selection criteria can be used. The two most common are the Akaike Information Criterion (AIC) and the Schwarz' Bayesian Information Criterion. In our tests (including unit root, cointegration and VECM) we have consistently chosen lags based on AIC, following Liew \&Sen (2004), who find that the AIC is superior in the context of small sample (60 observations or below).
} 
Results of Johansen \& Juselius (1990) cointegration test are also reported in Appendix Table 2 to check the robustness of a long-run relationship. ${ }^{8}$ We use the optimum lag lengths provided by AIC criterion. It is apparent from Appendix Table 2 that, for supply-side Equations (1) and (2) there are at most 3 and 2 cointegrating relationships among the variables. For the demand-side Equations 3, 4, 5, 6, 7, and 8 there exist at most 1, 2, 2, 3, 2 and 3 cointegrating relationships, respectively. Hence, these results suggest that there are long-run equilibrium relationships among the variables in each of the eight equations.

\subsection{Short-run and long-run estimates}

The cointegrating relationships among the variables indicate the existence of both short-run and long-run relationships among the variables. The ARDL based estimates for both long and short runs are presented in Table 5.

Results from both of the supply-side models indicate coal, oil and renewable energy consumptions are positively related to economic growth and the relationships are significant. This implies that all the three energy sources play a vital role to enhance economic growth in China. These findings are consistent with the findings of Yuan et. al. (2008) and Wang et. al. (2011) that energy use is a crucial input to production in China. The result nonetheless is contradictory to Zhang \& Xu (2012), who claim a negative impact of energy use on economic growth due to the use of energy in unproductive sectors. The results further suggest that in the long run, all else constant, a $1 \%$ growth in coal, oil, renewable energy and combined energy consumption is expected to increase output by $0.492,0.179,0.451$ and $0.711 \%$, respectively.

With regards to the demand-side, in the long-run economic growth plays a vital role in coal, oil and renewables consumption separately as well as jointly. Hence, there exists a long-run bi-directional causality among aggregate output and coal or oil or renewable energy separately as well as their combined consumption. A $1 \%$ increase in output leads to 0.819 , 1.572, 1.106 and $0.297 \%$ increase in coal, oil, renewables and combined consumption, respectively. The findings in Table 4 for cross-price elasticity in coal, oil and renewable energy consumption equations show clear prospects for fuel substitution. Oil price has a longrun elasticity of 2.316 with the coal consumption, while coal price has-long run elasticity of 1.972 with oil consumption. Further, coal and oil prices have positive elasticities of 2.711and

\footnotetext{
${ }^{8}$ We implemented the test within the option of intercept, no trend. This is done in accordance with the unit root test results, where all the test statistics with intercept are significant at $1 \%$ level but trend is not statistically significant.
} 
1.257, respectively, with renewable energy consumption. Hence, there exists clear opportunity of intra-fuel substitution among coal, oil and renewable energy in China. Most importantly, the large positive elasticity of renewable energy consumption to both coal and oil prices suggests a clear potential for reducing pollution emissions through raising the price of fossil fuels.

Negative coal and oil own-price elasticity suggest that the intensity of their separate use in production can be reduced through actions that raise their price in each case. The ownprice elasticity for coal is -0.848 and for oil is-1.762 in the long run. All the short-run causality directions are also consistent with long-run elasticities. Further, it is notable that combined use of coal, oil and renewable energy has no statistically significant relationship with the combined price index for coal and oil in either the short or long run. Thus, an increase in the price of either coal or oil apparently does not reduce overall energy consumption, suggesting that there need not be an adverse effect on economic growth from raising the price of either fossil fuel.

Using a simple OECD spreadsheet model for a period of 1986 to 2004, Brook et. al. (2004) find long-run oil demand price elasticity as -0.20. A further OECD study of oil demand in China by Fournier et. al. (2013) uses an error correction model within the constant elasticity of substitution (CES) production function framework. The long-run and short-run price elasticity are found by the authors to be -0.238 and 0.083 , respectively. These oil price elasticity estimates are much smaller than our estimates. Jiao et. al. (2009) use a time-series method similar to our own to estimate price elasticity for coal demand over the period 1980 to 2006. They find long-run price elasticity of -1.161 and short run elasticity of -0.067 , estimates that are not dissimilar from our own.

The emission equations in the last two columns of Table 5 show how coal, oil and renewable energy consumption separately impact on emissions. In the second last column, coal consumption significantly increases pollutant emission in both the short run and the long run, while oil consumption only has a weak short-run impact on emission and no significant impact in the long run. Renewable energy has negative impact on pollution. In the short run there exists a unidirectional causality running from renewable energy to emission. These results clearly indicate that increased adoption of renewable energy in China can help reduce emission significantly both in short and long run. The last column indicates that combined energy consumption of all three types is positively and significantly related to emissions in both the short and long run. Clearly, it is changing the composition of energy consumption 
away from coal and towards oil and, especially, renewables that is the key to reducing emissions with reducing economic growth in China.

Table 5: ARDL Long-Run and Short-Run Results

\begin{tabular}{|c|c|c|c|c|c|c|c|c|}
\hline \multirow{2}{*}{$\begin{array}{l}\begin{array}{l}\text { Estimated } \\
\text { models }\end{array} \\
\text { Series }\end{array}$} & \multicolumn{2}{|c|}{ Supply-side Analysis } & \multicolumn{6}{|c|}{ Demand-side Analysis } \\
\hline & $\begin{array}{l}\text { LY: LL, } \\
\text { LK, LC, } \\
\text { LO,RE }\end{array}$ & $\begin{array}{l}\text { LY: LL, } \\
\text { LK, } \\
\text { LCORE }\end{array}$ & $\begin{array}{l}\text { LC: LY, } \\
\text { LCP, LOP }\end{array}$ & $\begin{array}{c}\text { LO: LY, } \\
\text { LCP, LOP }\end{array}$ & $\begin{array}{c}\text { LO: LY, } \\
\text { LCP, } \\
\text { LOP }\end{array}$ & $\begin{array}{c}\text { LCORE: } \\
\text { LY, } \\
\text { LCOP }\end{array}$ & $\begin{array}{c}\text { LE: LY, } \\
\text { LC, LO, } \\
\text { LRE }\end{array}$ & $\begin{array}{l}\text { LE: LY, } \\
\text { LCORE }\end{array}$ \\
\hline \multicolumn{9}{|c|}{ Long-Run Analysis } \\
\hline LY & & & $0.819^{*}$ & $1.572 *$ & $1.106 * *$ & $0.297 * *$ & $0.338^{*}$ & $0.490 *$ \\
\hline LL & 0.046 & 0.667 & & & & & & \\
\hline LK & $1.021 *$ & $0.983 * * *$ & & & & & & \\
\hline $\mathrm{LC}$ & $0.492 *$ & & & & & & $1.150 *$ & \\
\hline LO & $0.179 * * *$ & & & & & & 0.012 & \\
\hline LRE & $0.451 * *$ & & & & & & $-0.481^{*}$ & \\
\hline LCORE & & $0.711 * * *$ & & & & & & $0.295 * *$ \\
\hline LCP & & & $-0.848^{*}$ & $1.972 * *$ & $2.711 *$ & & & \\
\hline LOP & & & $2.316^{*}$ & $-1.762 *$ & $1.257 *$ & & & \\
\hline LCOP & & & & & & 2.041 & & \\
\hline \multicolumn{9}{|c|}{ Short-Run Analysis } \\
\hline$\Delta \mathrm{LY}$ & & & $0.673 *$ & $0.851 *$ & $1.489 * *$ & 2.088 & $5.034 * *$ & $0.501 * *$ \\
\hline$\Delta \mathrm{LL}$ & 0.020 & 0.336 & & & & & & \\
\hline$\Delta \mathrm{LK}$ & $21.59 *$ & $23.435^{*}$ & & & & & & \\
\hline$\Delta \mathrm{LC}$ & 0.876 & & & & & & $53.765^{*}$ & \\
\hline$\Delta \mathrm{LO}$ & $4.032 * *$ & & & & & & 0.022 & \\
\hline$\Delta \mathrm{LRE}$ & $7.628 *$ & & & & & & $6.773^{*}$ & \\
\hline$\Delta$ LCORE & & $4.663 * *$ & & & & & & $82.604 *$ \\
\hline$\Delta \mathrm{LCP}$ & & & $-0.154 *$ & $0.051 *$ & $1.072 *$ & & & \\
\hline$\Delta \mathrm{LOP}$ & & & $0.335 * * *$ & -0.305 & $1.170 * *$ & & & \\
\hline$\Delta \mathrm{LCOP}$ & & & & & & 0.196 & & \\
\hline $\mathrm{ECM}_{\mathrm{t}-1}$ & $-0.133^{*}$ & -0.037 & $-0.647^{*}$ & $-0.192 *$ & $-0.015^{* *}$ & $-0.021 *$ & $-0.200^{*}$ & $-0.017 * *$ \\
\hline $\mathrm{R}^{2}$ & 0.818 & 0.999 & 0.732 & 0.626 & 0.803 & 0.997 & 0.960 & 0.937 \\
\hline F- & $16.130^{*}$ & & $15.015^{*}$ & $15.127 *$ & $8.538 *$ & $4.905 * *$ & $9.021 *$ & $41.329 *$ \\
\hline Statistics & & & & & & & & \\
\hline D.W. & 1.794 & & 1.797 & 1.874 & 1.958 & 2.353 & 2.204 & 1.980 \\
\hline
\end{tabular}

To check parameter stability we implement the CUSUM test and find that all the parameters used in each of the models are sufficiently stable. ${ }^{9}$ The Chow forecast test is also employed to investigate structural changes in the economy for periods of 1977 to 2012 and 1965 to 2011 for supply-side and demand-side analysis, respectively. Macroeconomic series are often affected by exogenous shocks or regime shifts. For example, during the studied period China has gone through several macroeconomic changes, including reforms in energy regulations and institutional developments in 1980s and 1990s. China also adopted an open

\footnotetext{
${ }^{9}$ Detailed results of the CUSUM tests are available on request from the authors.
} 
door policy since 1978. These structural reforms, market incentives, and decentralization policies led to rapid growth in the energy sector since the late 1980s. These changes may alter the effects of the variables we use. However, the results of the Chow forecast test suggest that there are no significant structural breaks in the effects of any of the variables during the sample periods for both supply-side and demand-side models (Appendix Table 3). These results further confirm that the ARDL estimates are reliable.

We implement a vector error correction (VECM) model to investigate the robustness of ARDL model and identify causal relationships in greater detail. Such knowledge is helpful in crafting appropriate energy policies for sustainable growth. Table 6 reports results for the direction of long-run and short-run causality.

The results are consistent with the findings of ARDL model. There exists bidirectional causality between growth and coal and/or oil and/or renewable energy consumption. Coal, renewable energy and combined coal-oil-renewable energy consumption Granger cause pollution emission, but no significant causality is found from oil consumption to pollution.

Table 6: VECM Granger Causality Test

\begin{tabular}{|c|c|c|c|c|c|c|c|c|}
\hline \multirow{2}{*}{\begin{tabular}{|l|} 
Model \\
Series
\end{tabular}} & \multicolumn{2}{|c|}{ Supply-side } & \multicolumn{2}{|c|}{ Demand-side } & \multirow[b]{2}{*}{$\begin{array}{l}\text { LO: LY, } \\
\text { LCP, } \\
\text { LOP }\end{array}$} & \multirow[b]{2}{*}{$\begin{array}{l}\text { LCO: } \\
\text { LY, } \\
\text { LCOP }\end{array}$} & \multirow[b]{2}{*}{$\begin{array}{l}\text { LE: LY, } \\
\text { LC, LO, } \\
\text { LRE }\end{array}$} & \multirow[b]{2}{*}{$\begin{array}{l}\text { LE: LY, } \\
\text { LCORE }\end{array}$} \\
\hline & $\begin{array}{l}\text { LY: LL, } \\
\text { LK, LC, } \\
\text { LO, } \\
\text { LRE }\end{array}$ & $\begin{array}{l}\text { LY: LL, } \\
\text { LK, } \\
\text { LCORE }\end{array}$ & $\begin{array}{l}\text { LC: } \quad \text { LY, } \\
\text { LOP, LCP }\end{array}$ & $\begin{array}{l}\text { LO: LY, } \\
\text { LCP, } \\
\text { LOP }\end{array}$ & & & & \\
\hline \multicolumn{9}{|c|}{ Short-run analysis } \\
\hline$\Delta \mathrm{LY}$ & & & $4.901 *$ & $2.526^{*}$ & $2.917 * * *$ & 0.806 & $0.646 * *$ & 1.460 \\
\hline$\Delta \mathrm{LL}$ & 1.297 & 2.370 & & & & & & \\
\hline$\Delta \mathrm{LK}$ & $33.173 *$ & $15.78 *$ & & & & & & \\
\hline$\Delta \mathrm{LC}$ & $2.119 * *$ & & & & & & $0.185^{*}$ & \\
\hline$\Delta \mathrm{LO}$ & $0.242 * *$ & & & & & & 0.347 & \\
\hline$\Delta \mathrm{LRE}$ & $0.769 * *$ & & & & & & $1.956 * *$ & \\
\hline$\Delta$ LCORE & & $7.634 *$ & & & & & & $9.513 *$ \\
\hline$\triangle \mathrm{LCP}$ & & & $3.254 *$ & $2.906^{*}$ & $0.908 * * *$ & & & \\
\hline$\Delta \mathrm{LOP}$ & & & $4.526 *$ & $2.524 * *$ & $4.176 * * *$ & & & \\
\hline$\triangle \mathrm{LCOP}$ & & & & & & 0.006 & & \\
\hline \multicolumn{9}{|c|}{ Long run analysis } \\
\hline $\mathrm{ECT}_{\mathrm{t}-1}$ & $-.004 * * *$ & $-0.022^{*}$ & $-0.044 *$ & $-0.196^{*}$ & -0.021 & $-0.049 *$ & $-0.101 *$ & $-0.084 *$ \\
\hline & $-0.018 * *$ & $-0.014 *$ & & $-0.189 *$ & $-0.108 *$ & -0.031 & -0.018 & -0.019 \\
\hline & $-0.017 *$ & & & & & $-0.019 *$ & & $-0.034 * *$ \\
\hline $\mathrm{R}^{2}$ & 0.784 & 0.791 & 0.838 & 0.937 & 0.883 & 0.702 & 0.740 & 0.694 \\
\hline F-Statistics & $11.848^{*}$ & $22.005^{*}$ & $18.505^{*}$ & $6.926 *$ & $3.436 *$ & $6.430 *$ & $5.017 *$ & $6.199 *$ \\
\hline D.W. & 2.015 & 1.826 & 1.318 & 1.294 & 1.974 & 1.954 & 2.003 & 2.251 \\
\hline
\end{tabular}

The Granger causality tests suggest which variables in the system have significant impacts on the future values of each of the variables in the system. However, the results do not, by construction, indicate how long these impacts will remain effective. Variance 
decomposition gives this information. Hence, we conduct generalized variance decompositions analysis proposed by Koop et al. (1996) and Pesaran \& Shin (1998). A distinguishing feature of this approach is that the results from this analysis are invariant to the ordering of the variables entering the VAR system. The VECM results for supply-side and demand-side models are reported in Table 7 and Table 8, respectively.

Variance decomposition gives proportion of the movement in the dependent variable that is due to its 'own' shocks versus shocks to the other variables. The results of variance decomposition in Table 7 for the supply-side model with separate coal, oil and renewable energy data over a period of 20 -year time horizon indicate that after five years, $64.4 \%$ of the variation in the forecast error for output is explained by its own innovations, while at the end of twenty years, this drops to only $20.7 \%$. In contrast, coal consumption explains almost $17.0 \%$ of output after 5 years rising to $64.1 \%$ after 20 years. Thus, shocks to coal consumption have long lasting impact on production in China. Shocks to oil and renewable energy consumption have a smaller role in explaining variance in aggregate output. The pattern of results for combined coal, oil and renewable energy in the second model of Table 8 is similar to that observed for coal. After 5 years $63.2 \%$ variations in output is explained by its own innovations, while after 20 years this drops down to $19.4 \%$. Shocks to coal-oilrenewables combined explain only $28.2 \%$ variations in 5 years, but increase to $64.6 \%$ after 20 years.

Table 7: Generalized Forecast Error Variance Decomposition for Supply-side Equations

\begin{tabular}{lllllllll}
\hline Series/ Estimated models & Horizon & LY & LL & LK & LC & LO & LRE & LCORE \\
\hline LY & 1 & 0.644 & 0.093 & 0.382 & 0.170 & 0.014 & 0.152 & \\
& 5 & 0.394 & 0.138 & 0.437 & 0.453 & 0.119 & 0.042 & \\
LY: LL, LK, LC, LO, LRE & 10 & 0.338 & 0.064 & 0.152 & 0.596 & 0.073 & 0.033 & \\
& 15 & 0.256 & 0.030 & 0.055 & 0.640 & 0.049 & 0.026 & \\
LY & 20 & 0.207 & 0.017 & 0.029 & 0.641 & 0.038 & .0220 & \\
& 1 & 0.632 & 0.100 & 0.534 & & & & 0.282 \\
LY: LL, LK, LCORE & 5 & 0.495 & 0.082 & 0.404 & & & & 0.569 \\
& 10 & 0.367 & 0.027 & 0.129 & & & & 0.656 \\
& 15 & 0.260 & 0.018 & 0.056 & & & & 0.664 \\
& 20 & 0.194 & 0.023 & 0.038 & & & & 0.646 \\
\hline
\end{tabular}

Note: All figures are estimates rounded to three decimal places.

Table 8 reports variance decomposition results of the demand-side models. Other than its own innovation, coal consumption is increasingly explained by economic growth and its own price. For oil consumption, other than its own innovations, variations are increasingly explained by coal prices. After 5 years $0.2 \%$ of variations in oil consumption can be 
explained by the innovation in coal prices, while after 20 years $46.7 \%$ of variations in oil consumption is explained by coal prices.

Table 8: Generalized Forecast Error Variance Decomposition for Demand-side Equations

\begin{tabular}{|c|c|c|c|c|c|c|c|c|c|c|}
\hline $\begin{array}{l}\text { Series/ } \\
\text { Estimated } \\
\text { models }\end{array}$ & $\begin{array}{l}\text { Horiz } \\
\text { on }\end{array}$ & LY & $\mathrm{LC}$ & $\mathrm{LO}$ & LRE & LCORE & LE & $\mathrm{LCP}$ & LOP & LCOP \\
\hline $\mathrm{LC}$ & 1 & 0.431 & 0.899 & & & & & 0.236 & 0.021 & \\
\hline & 5 & 0.412 & 0.896 & & & & & 0.224 & 0.018 & \\
\hline & 10 & 0.389 & 0.890 & & & & & 0.212 & 0.015 & \\
\hline LC: LY, LCP, & 15 & 0.368 & 0.882 & & & & & 0.209 & 0.013 & \\
\hline LOP & 20 & 0.348 & 0.873 & & & & & 0.202 & 0.011 & \\
\hline $\mathrm{LO}$ & 1 & 0.316 & & 0.958 & & & & 0.002 & 0.129 & \\
\hline & 5 & 0.311 & & 0.841 & & & & 0.061 & 0.182 & \\
\hline & 10 & 0.302 & & 0.682 & & & & 0.221 & 0.134 & \\
\hline I O. I Y I CP & 15 & 0.281 & & 0.545 & & & & 0.365 & 0.097 & \\
\hline LOP & 20 & 0.265 & & 0.449 & & & & 0.467 & 0.074 & \\
\hline LRE & 1 & 0.101 & & & 0.848 & & & 0.028 & 0.120 & \\
\hline & 5 & 0.063 & & & 0.435 & & & 0.071 & 0.321 & \\
\hline LO: LY, LCP, & 10 & 0.031 & & & 0.275 & & & 0.135 & 0.354 & \\
\hline LOP & 15 & 0.019 & & & 0.208 & & & 0.194 & 0.325 & \\
\hline & 20 & 0.013 & & & 0.162 & & & 0.256 & 0.284 & \\
\hline LCORE & 1 & 0.034 & & & & 0983 & & & & 0.012 \\
\hline & 5 & 0.040 & & & & 0.926 & & & & 0.054 \\
\hline & 10 & 0.113 & & & & 0.824 & & & & 0.047 \\
\hline & 15 & 0.190 & & & & 0.723 & & & & 0.046 \\
\hline $\begin{array}{l}\text { LCO: } \quad \text { LY, } \\
\text { LCOP }\end{array}$ & 20 & 0.241 & & & & 0.652 & & & & 0.045 \\
\hline LE1 & 1 & 0.048 & 0.829 & 0.014 & 0.011 & & 0.970 & & & \\
\hline & 5 & 0.021 & 0.728 & 0.079 & 0.194 & & 0.483 & & & \\
\hline & 10 & 0.009 & 0.713 & 0.119 & 0.232 & & 0.360 & & & \\
\hline LE: LY, LC, & 15 & 0.006 & 0.687 & 0.190 & 0.273 & & 0.360 & & & \\
\hline LO, LRE & 20 & 0.005 & 0.679 & 0.196 & 0.323 & & 0.374 & & & \\
\hline LE2 & 1 & 0.014 & & & & 0.843 & 0.996 & & & \\
\hline & 5 & 0.153 & & & & 0.616 & 0.656 & & & \\
\hline & 10 & 0.171 & & & & 0.526 & 0.545 & & & \\
\hline & 15 & 0.262 & & & & 0.498 & 0.517 & & & \\
\hline $\begin{array}{l}\text { LE: } \\
\text { LCORE }\end{array}$ & 20 & 0.321 & & & & 0.481 & 0.510 & & & \\
\hline
\end{tabular}

With respect to the emission equations, most of the variations in emission can be explained by its own innovations and the innovations in coal consumption. In the first 
emission equation, coal consumption explains approximately $82.9 \%$ of the variations in emission after 5 years and after 20 years this is still almost $67.9 \%$. In contrast, the impact of oil consumption is relatively small at any time horizon. These results further the argument that fuel substitution from coal to oil and/or renewable energy would lower pollution and enhance environmental sustainability.

\section{Conclusions and Policy Implications}

This paper investigates the relationship between aggregate output and energy consumption in form of coal, oil and renewable energy in China using both a supply-side and a demand-side framework. The ARDL technique and vector error correction model (VECM) are used to examine both short-run and long-run dynamic relationships. Structural break tests and several investigative techniques, including Chow and generalized forecast error variance decompositions, are employed to check for the robustness of the results. The impact coal, oil and renewable energy consumption separately and jointly are considered in relation to the unprecedented economic growth of China.

According to the findings from both the supply-side and demand-side equations, there is long-run bi-directional causality between GDP and coal, oil and renewable energy consumption, separately or jointly, where GDP is a measure of aggregate output. Thus, it is difficult for China to reduce coal and oil consumption without adversely affecting national output. However, switching to greener energy sources might be possible. We find a strong prospect for fuel substitution from coal to oil and/or renewable energy in terms of positive cross-price elasticity in the demand equation for coal, oil and also for renewable energy. We also find negative own-price elasticity for each of coal, oil and their combination, suggesting the use of both fossil fuels falls with rising prices.

In support of the proposition that renewable energy or even oil consumption is less polluting than coal consumption, we find that there is unidirectional causality running from coal consumption to pollution emission, while the impact of oil consumption on emission is insignificant. The impact of renewable energy on pollution is significantly negative. . If coal ceases to be a 'cheap' source of energy through carbon pricing or other policies, then fuel substitution from coal to oil and/or renewables should be very much a reality. Also, raising the price of either coal or oil reduces their use and increases the use of renewable energy, further reducing carbon emissions. Overall, the message is clear that increased prices for fossil fuels would support enhancing the sustainability of further economic growth in China. 


\section{References}

Apergis, N., \& Tang, C. F., (2013). Is the Energy-Led Growth Hypothesis Valid? New Evidence from a sample of 85 Countries. Energy Economics, 38, 24-31.

Asafu-Adjaye, J., (2000). The relationship between energy consumption, energy prices and economic growth: time series evidence from Asian developing countries. Energy Economics, 22(6), 615-625.

Bannerjee, A., Dolado, J., \& Mestre, R., (1998). Error-correction mechanism tests for cointegration in single equation framework. J. Time Ser. Anal., 19, 267-283.

Belke, A., Dobnik, F., \& Dreger, C., (2011). Energy consumption and economic growth: new insights into the cointegration relationship. Energy Economics 33(5), 782-789.

Bloch, H., Rafiq, S., \& Salim, R. A., (2012). Coal Consumption, CO2 Emission and Economic Growth in China: empirical Evidence and Policy Responses. Energy Economics, 34, 518-528.

BP., (2013). BP Statistical Review of World Energy Retrieved 28 August 2013, from http://www.bp.com/productlanding.do?categoryId=6929\&contentId=7044622

Brook, A., Anne-Marie, Price, Robert W., Sutherland, Douglas, Westerlund, Niels \& André, Christophe. (2004). Oil Price Developments: Drivers, Economic Consequences and Policy Responses. OECD Economics Department Working Papers, No. 412, OECD Publishing.

Brown, R. L., Durbin, J., \& Ewans J. M., (1975). Techniques for testing the constancy of regression relations overtime. J. R. Stat. Soc., 37, 149-172.

Crompton, P., \& Wu, Y., (2005). Energy consumption in China: Past trends and future directions. Energy Economics, 27, 195-208.

Dept. of Environment Australia (DEA), (2014). China: Acting on Climate Change Retrieved

9 September 2014, from http://www.climatechange.gov.au/international/actions/countriesacting-now/china-acting-climate-change.

EIA, (2014). Country Analysis Brief Retrieved 9 September 2014, from http://www.eia.gov/countries/cab.cfm?fips=CH

Fournier, Jean-Marc, Koske, Isabell, Wanner, Isabelle \& Zipperer, Vera, (2013). The Price of Oil - Will it Start Rising Again?, OECD Economics Department Working Papers, No. 1031, OECD Publishing.

Fuinhas, J. A., \& Marques, A. C., (2012). Energy consumption and economic growth nexus in Portugal, Italy, Greece, Spain and Turkey: an ARDL bounds test approach (19652009). Energy Economics, 34(2), 511-517.

Goldemberg, J., \& Lucon O., (2010). Energy, Environment and Development (2nd Edition ed.). London: Earthscan.

Govindaraju, V. G. R. C., \& Tang, C. F., (2013). The dynamic links between CO2 emissions, economic growth and coal consumption in China and India. Applied Energy, 104, 310-318.

Haley, U. C. V., \& Haley, G. T., (2008). Subsidies and the China Price. [Article].

Harvard Business Review, 86(6), 25-26.

Jiao, Jian-Ling, Fan, Ying \& Wei, Yi-Ming, (2009). The structural break and elasticity of coal demand in China: empirical findings from 1980-2006. Int. J. Global Energy Issues, 31(3/4), 331-344

Johansen, S., (1988). Statistical analysis of cointegration vectors. Journal of Economic Dynamics and Control, 12(2-3), 231-254.

Johansen, S., \& Juselius, K., (1990). Maximum likelihood estimation and inference on cointigration with applications to the demand for money. Oxford Bulletin of Economics \& Statistics, 52(2), 169-210. 
Koop, G., Pesaran, M. H., \& Potters, S. M., (1996). Impulse response analysis in nonlinear multivariate models. Journal of Econometrics, 74(1), 119-147.

Kraft, J., \& Kraft, A., (1978). On the relationship between energy and GNP. Journal of Energy Development, 3, 401-403.

Lee, J., \& Strazicich, M. C., (2003). Minimum Lagrange multiplier unit root test with two structural breaks. Review of Economics and Statistics, 85(4), 1082-1089.

Lee, J., \& Strazicich, M. C., (2004). Minimum LM unit root test with one structural break. Department of Economics, Appalachian State University.

Liew \& Venus Khim-Sen, (2004) Which Lag Length Selection Criteria Should We Employ? Economics Bulletin, 3(33), 1-9.

Ma, H., Oxley, L., Gibson, J., \& Kim, B., (2008). China's energy economy: technical change, factor demand and interfactor/interfuel substitution. Energy Economics, 30(5), 2167-2183.

Narayan, P. K., (2005). The saving and investment nexus for China: evidence from cointegration test. Applied Economics, 17, 1979-1990.

Narayan, P. K., \& Smyth, R., (2005). Electricity consumption, employment and real income in Australia: evidence from multivariate Granger causality tests. Energy Policy, 33(9), 1109-1116.

Oh, W., \& Lee, K., (2004). Energy consumption and economic growth in Korea: testing the causality relation. Journal of Policy Modeling, 26(8-9), 973-981.

Ozturk, I., (2010). A literature survey on energy-growth nexus. Energy Policy, 38(1), 340-349.

Perron, P., (1989). The great crash, the oil price shocks, and the unit root hypothesis.

Econometrica, 57(6), 1361-1401.

Pesaran, M. H., \& Shin, Y., (1998). Generalized impulse response analysis in linear multivariate models. Economics Letters, 58(17-29).

Pesaran, M. H., \& Shin, Y., (1999). An autoregressive distributed lag modelling approach to cointegration analysis. Paper presented at the Econometric and Economic Theory in the Twentieth Century: The Ragnar Frisch Centennial Symposium Cambridge.

Pesaran, M. H., Shin, Y., \& Smith, R. J., (2001). Bounds testing approaches to the analysis of level relationships Journal of Applied Econometrics, 16(3), 289-326.

Rafiq, S., \& Salim, R. A., (2009). Temporal causality between energy consumption and income in six Asian emerging countries. Applied Economics Quarterly, 55(4), 1-16.

Salim, Ruhul A. and Bloch, Harry, (2009). Business expenditures on R\&D and trade performances in Australia: is there a link? Applied Economics. 41 (3), 351-361.

Shahbaz, M., Khan, S., \& Tahir, M. I., (2013). The dynamic links between energy consumption, economic growth, financial development and trade in China: fresh evidence from multivariate framework analysis. Energy Economics, 40(0), 8-21.

Soytas, U., \& Sari, R., (2006). Energy consumption and income in G-7 countries. Journal of Policy Modeling, 28(7), 739-750.

Stern, D. I., (1993). Energy and economic growth in the USA: a multivariate approach. Energy Economics, 15(2), 137-150.

Stern, D. I., (2000). A multivariate cointegration analysis of the role of energy in the US macroeconomy. Energy Economics, 22(2), 267-283.

Tugcu, C. T., Ozturk, I., \& Aslan, A., (2012). Renewable and non-renewable energy consumption and economic growth relationship revisited: evidence from G7 countries. Energy Economics, 34, 1942-1950.

Umbach, Frank. (2010). EU-China energy relationships and geopolitics: The challenges for cooperation. In The Globalization of Energy: China and the European Union, Mehdi Parvizi Amineh, Yang Guang (ed.), 31-51. 
Wang, Y., Wang, Y., Zhou, J., Zhu, X., \& Lu, G., (2011). Energy consumption and economic growth in China: a multivariate causality test. Energy Policy, 39, 43994406.

Wolde-Rufael, Y., (2004). Disaggregated industrial energy consumption and GDP: the case of Shanghai, 1952-1999. Energy Economics, 26(1), 69-75.

World Bank, (2013). World Bank Country Brief Retrieved 23 August, 2013, from http://www.worldbank.org/en/country

Yuan, J. H., Kang, J. G., Zhao, C. H., \& Hu, Z. G., (2008). Energy consumption and economic growth: evidence from China at both aggregate and disaggregate levels. Energy Economics, 30, 3077-3094.

Zhang, C., \& Xu, J., (2012). Retesting the causality between energy consumption and GDP in China: evidence from sectoral and regional analyses using dynamic panel data. Energy Economics, 34, 1782-1789. 
Appendix Table 1: 2013 Primary Energy Consumption by Fuel in China (mtoe)

\begin{tabular}{llccc}
\hline Energy Source & China & World & Yearly \% Change & \% of World \\
\hline Oil & 507.4 & 4185.1 & $3.8 \%$ & $12.1 \%$ \\
Natural Gas & 145.5 & 3020.4 & $10.8 \%$ & $4.8 \%$ \\
Coal & 1925.3 & 3826.7 & $4.0 \%$ & $50.3 \%$ \\
Nuclear Energy & 25.0 & 563.2 & $13.9 \%$ & $4.4 \%$ \\
Hydroelectricity & 206.3 & 855.5 & $4.8 \%$ & $24.1 \%$ \\
Solar & 11.9 & 124.8 & $91.3 \%$ & $9.5 \%$ \\
Wind & 131.9 & 628.2 & $37.8 \%$ & $21.0 \%$ \\
Geo Biomass & 10.4 & 108.9 & - & $9.5 \%$ \\
Other Renewables & 42.9 & 279.3 & 28.3 & $15.4 \%$ \\
Total & 2852.4 & 12730.4 & $4.7 \%$ & $22.4 \%$ \\
\hline
\end{tabular}

Note: Primary energy comprises commercially traded fuels including modern renewables used to generate electricity. Oil consumption is measured in million tonnes; other fuels in million tonnes of oil equivalent. "Yearly \% Change" and "\% of World" represent percentage change in consumption from 2012 to 2013 and percentage of total world consumption for the same fuel Source: BP (2013) 
Appendix Figure 1a: Variables Used in the Supply-side Analysis
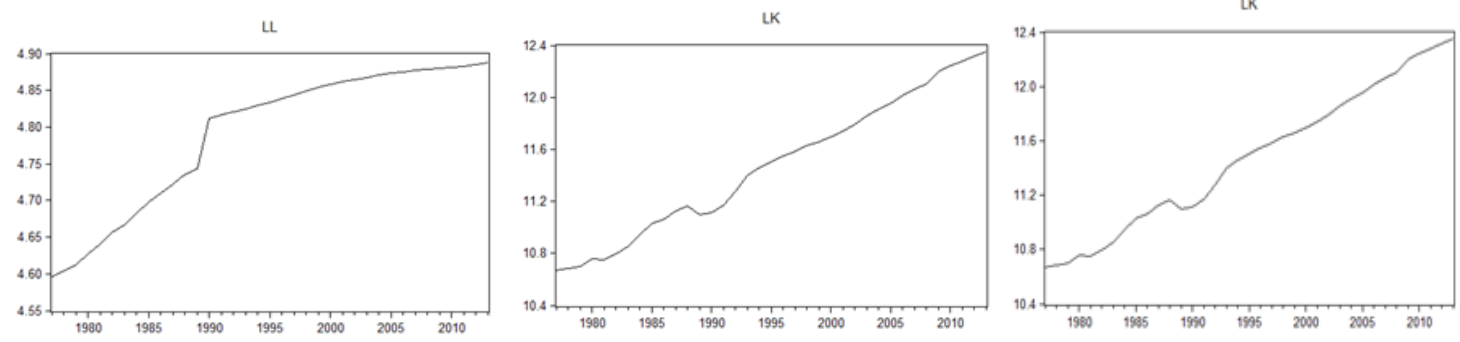

to
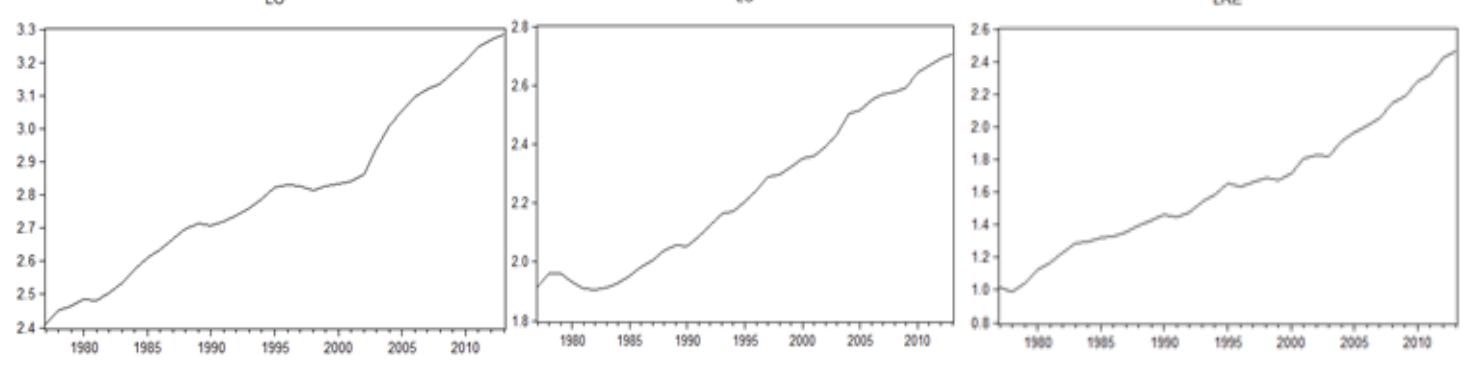

LCORE

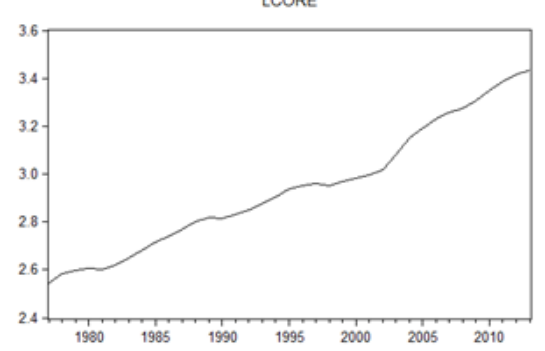

Appendix Figure 1b: Variables Used in the Demand-side Analysis
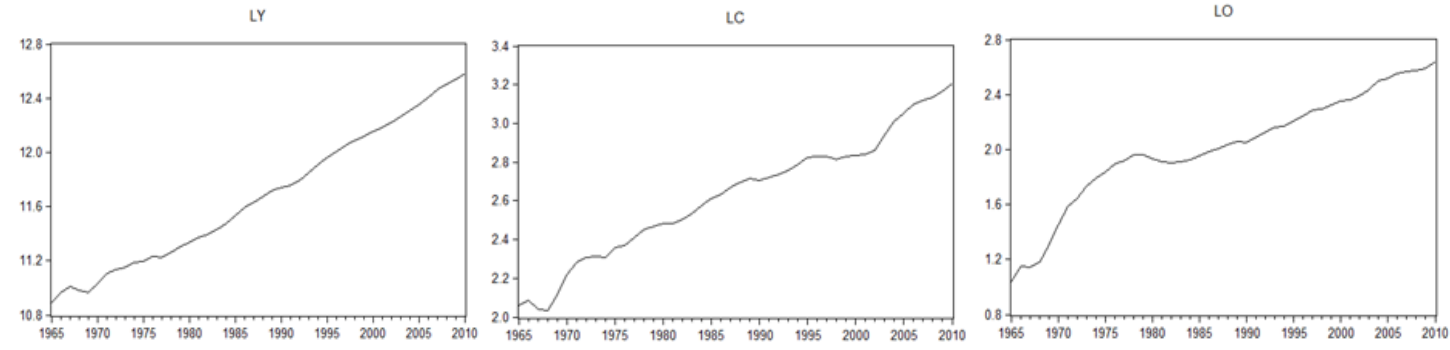

LRE

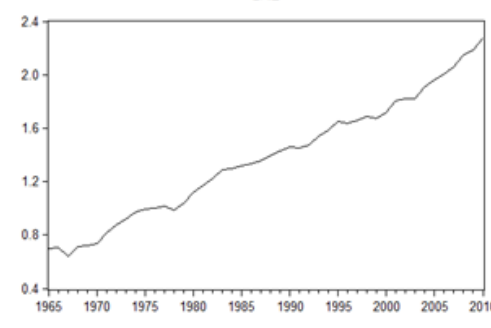

LCORE
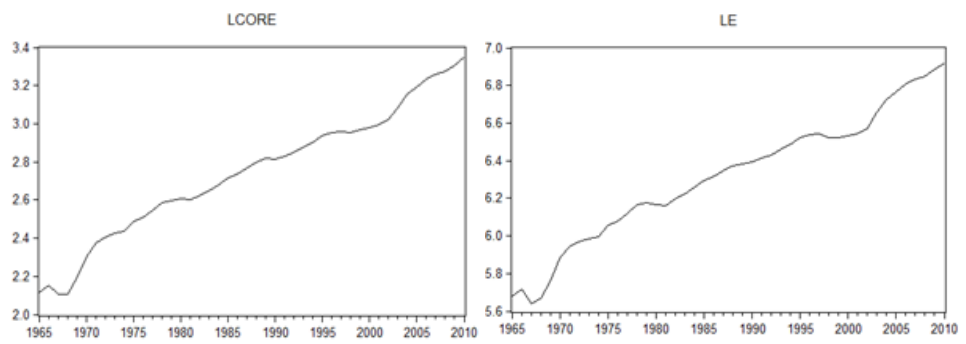

tce
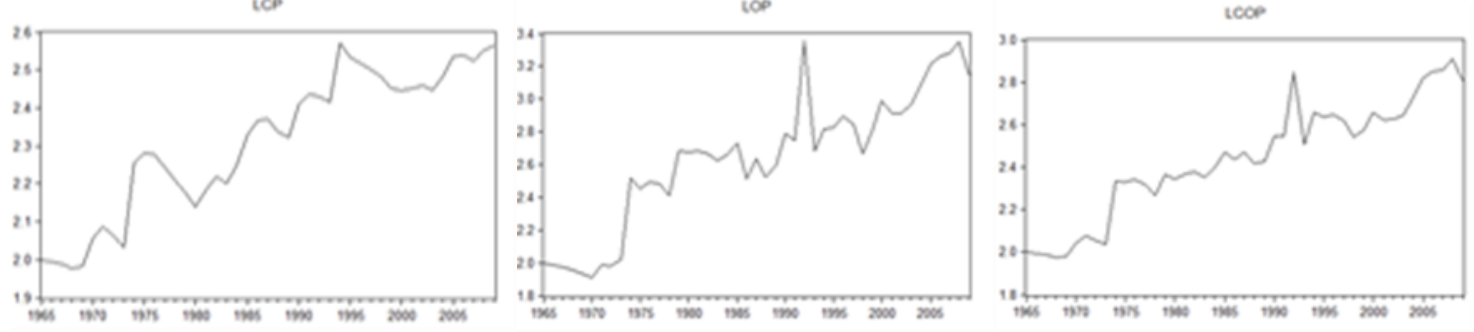

Note: LY, LL, LK, LC, LO, LRE, LCORE, LE, LCP, LOP and LCOP stand for log of output, labor, capital, oil consumption, coal consumption, renewable energy consumption, aggregate coal, oil 
and renewables consumption, pollutant emission, coal price, oil price and combined coal and oil price, respectively. 
Appendix Table 2: Johansen's Test for Multiple Cointegrating Relationships [Intercept, no Trend]

\begin{tabular}{|c|c|c|c|c|c|}
\hline Sides & Estimated models & Null & Optimal lag & Max eig. & Trace Stat. \\
\hline \multirow{5}{*}{$\underline{\text { Supply-side }}$} & \multirow{6}{*}{$\begin{array}{c}\text { LY: LL, LK, LC, LO, } \\
\text { LRE }\end{array}$} & $r=0$ & 1 & $56.698 * *$ & $172.655 * *$ \\
\hline & & $r \leq 1$ & & $44.828 * *$ & $115.957 * *$ \\
\hline & & $r \leq 2$ & & $34.724 * *$ & $71.129 * *$ \\
\hline & & $r \leq 3$ & & 17.851 & $36.404 * *$ \\
\hline & & $r \leq 4$ & & 10.399 & $18.553 * * *$ \\
\hline \multirow{9}{*}{$\underline{\text { Analysis }}$} & & $r \leq 5$ & & 8.153 & $8.153 * * *$ \\
\hline & \multirow[t]{4}{*}{ LY: LL, LK, LCORE } & $r=0$ & 2 & $38.240 * *$ & $75.486^{* *}$ \\
\hline & & $r \leq 1$ & & $17.654 * *$ & $37.246 * *$ \\
\hline & & $r \leq 2$ & & 12.779 & 16.592 \\
\hline & & $r \leq 3$ & & 6.813 & 6.813 \\
\hline & LC: LY, LCP, LOP & $r=0$ & 2 & $20.720 * *$ & $41.139 * *$ \\
\hline & & $r \leq 1$ & & 11.095 & 12.418 \\
\hline & & $r \leq 2$ & & 9.323 & 9.323 \\
\hline & & $r \leq 3$ & & 6.427 & 5.145 \\
\hline \multirow{19}{*}{$\frac{\text { Demand-side }}{\underline{\text { Analysis }}}$} & LO: LY, LCP, LOP & $r=0$ & 2 & $76.919 * *$ & $112.070 * *$ \\
\hline & & $r \leq 1$ & & $22.063 * *$ & $35.150 * *$ \\
\hline & & $r \leq 2$ & & 7.974 & 13.086 \\
\hline & & $r \leq 3$ & & 5.111 & 5.111 \\
\hline & LRE: LY, LCP,LOP & $r=0$ & 4 & $22.532 * *$ & $52.659 * *$ \\
\hline & & $r \leq 1$ & & $16.409 * *$ & $30.127 * *$ \\
\hline & & $r \leq 2$ & & 11.717 & 10.717 \\
\hline & & $r \leq 3$ & & 8.951 & 8.482 \\
\hline & & $r=0$ & 3 & $33.836^{* *}$ & $74.022 * *$ \\
\hline & LCO: LY, LCOP & $r \leq 1$ & & $23.047 * *$ & $40.185^{* *}$ \\
\hline & & $r \leq 2$ & & $16.841 * *$ & $17.138^{* *}$ \\
\hline & LE: LY, LC, LO, & $r=0$ & 4 & $68.586^{* *}$ & $130.494 * *$ \\
\hline & LRE & $r \leq 1$ & & $29.177 * *$ & $61.907 * *$ \\
\hline & & $r \leq 2$ & & 16.638 & 31.730 \\
\hline & & $r \leq 3$ & & 9.581 & 16.092 \\
\hline & & $r \leq 4$ & & 6.510 & 6.510 \\
\hline & & $r=0$ & 4 & $38.677 * *$ & $66.875^{* *}$ \\
\hline & LE: LY, LCORE & $r \leq 1$ & & $17.108 * *$ & $28.198 * *$ \\
\hline & & $r \leq 2$ & & $11.089 * *$ & $11.089 * *$ \\
\hline
\end{tabular}

Note: Cointegration with restricted intercepts and no trends in the VAR. $r$ indicates number of cointegrations. The optimal lag length of VAR is selected by AIC. Critical values are based on Johansen and Juselius (1990). *, **, and *** indicate significant at 1\%, 5\%, and $10 \%$ level, respectively. 
Appendix Table 3: Chow forecast test

Chow forecast test: Forecast from 2000 to 2011

\begin{tabular}{llll}
\hline Supply-side analysis & & & \\
F-statistics & 1.5319 & Probability & 0.2913 \\
Log likelihood ratio & 2.1394 & Probability & 0.1361 \\
\hline Demand-side analysis & & & \\
F-statistics & 1.0461 & Probability & 0.1783 \\
Log likelihood ration & 1.7928 & Probability & 0.1073
\end{tabular}

